\title{
A mathematical model for the delivery routing problem via drones
}

\section{Drone ile teslimat rotalaması için bir matematiksel model}

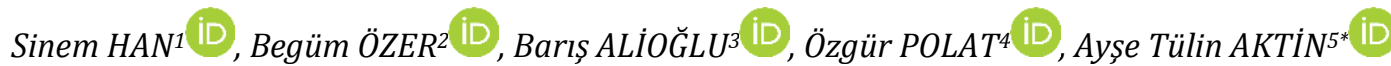

1,2,3,4,5Department of Industrial Engineering, Engineering Faculty, İstanbul Kültür University, İstanbul, Turkey. sinemhan94@hotmail.com, begumozer17@gmail.com, barisalioglu123@gmail.com,ozgurpolat7@gmail.com, t.aktin@iku.edu.tr

\begin{abstract}
Logistics sector aims to distribute merchandise to designated places on time, while focusing on the entire process that starts from storing the goods at warehouses. Transportation by land is the most common and preferred way in logistics in terms of cost and service. Studies have been going on for drone transportation with the purpose of reducing the service time and making the process automated. Advancement of this technology has led to an increase in transportation with drones. Traffic is a huge problem in land transportation causing delays in delivery time. Furthermore, nature and economy are affected because of the $\mathrm{CO}_{2}$ emission, which is a consequence of intense traffic. In this study, utilizing drones for delivery is proposed with the aim of increasing customer satisfaction and minimizing transportation cost per delivery in a green way. Istanbul's Bakırköy district is selected as the implementation region, and daily drug delivery to pharmacies with drones is examined. In the first stage, a mathematical model that uses pharmacy coordinates as an input is developed for clustering analysis. In the second stage, one of these clusters is selected, and the location of the drone center that will serve pharmacies in the cluster is obtained by center of gravity method. Then, a vehicle routing model is proposed for finding the drone routes and calculating the total distance travelled within this cluster. Mathematical models are solved with GAMS/CPLEX solver. It is believed that this study will trigger new studies in "green delivery" literature in near future.
\end{abstract}

Keywords: Drone, Vehicle routing problem, Mathematical modelling

\section{Introduction}

In today's competitive business environment, companies are adopting new technologies, and increasing their product and service variety. The target of these activities is to maximize the customer satisfaction, and the quality of services and products offered. Logistics occupies an important place in achieving these activities. It can be described as a business plan for organization of goods, services, information and capital movements. It is not only the movement of products and documents; it also extents to the integration from receiving orders to storage. Delivery, distribution, storage, customs clearance of goods and certification are the sub-functions of national and international trades. Logistics is one of the vital activities for profitability and productivity of companies. Similarly, value in the national economy and being involved in all sector branches are the additional advantages. Changes and formations in global trade affect logistics and transport sector. Reducing the cost of goods and services, succeeding in the
Öz

Lojistik, bir ürünün nakliyesinin yanı sıra, depolanması, ambalajlanması ve dağıtımı gibi süreçleri de kapsamakta ve tüm sürecin, ilk üreticiden nihai tüketiciye kadar doğru bir biçimde çalısmasını hedeflemektedir. Maliyet ve hizmet bakımından uygun bulunan karayolu taşımacılı̆̆ı, günümüzde tercih edilen ulaşım sistemlerinin bașında gelmektedir. Ancak gelișen teknolojiyle birlikte, birçok ürünün dağıtımında drone'lardan da yararlanıldığı görülmektedir. Bekleme zamanlarını azaltmayı ve insangücü maliyetin ortadan kaldırmayı amaçlayan bu sistem, yeni bir teslimat aracı olarak lojistik sürecinde yerini almıştır. Karayolunda oluşan trafik yoğunluğu, ürünlerin müsteriye ulasmasını geciktirmekte, bu sirada artan $\mathrm{CO}_{2}$ salımı da çevre ve ekonomi üzerinde olumsuz etkilere neden olmaktadır. Bu çalıșmanın amacı, drone kullanımı ile hızlı ve doğa dostu bir teslimat gerçekleștirmek suretiyle müșteri memnuniyetinde artıș ve tașıma maliyetlerinde azalma sağlamak ve yukarıda bahsedilen problemlere bir çözüm sunmaktır. Calıșada, eczanelerin günlük ilac gereksinimlerinin drone'lar yardımıyla karşılanması ele alınmış ve bu amaçla, İstanbul'un Bakırköy ilçesi pilot bölge olarak seçilmiștir. Önerilen iki aşamal yöntemin ilk aşamasındaki matematiksel model, kümeleme analizi yapmaktadır. Bölgedeki eczanelerin koordinatları modele girdi olarak verilmiș ve eczane kümeleri olusturulmustur. Íkinci aşamada ise, olușturulan kümelerden birisi seçilerek, ağırlı merkezi yöntemiyle, burada bulunan eczanelere hizmet verecek olan drone merkezinin yeri bulunmuştur. Daha sonra, bu kümeye ait eczanelere ilaç dağıtımı yapılırken, aralarındaki toplam mesafeyi enküçükleyecek şekilde drone'ların teslimat rotalarını belirleyen bir araç rotalama modeli geliștirilmiștir. Modeller, GAMS/CPLEX çözücüsü ile çözülmüstür. Bu çalıșmanın yakın gelecekte literatürdeki "yeșil teslimat" alanındaki yeni araştırmaları tetikleyeceğine inanılmaktadır. Anahtar kelimeler: Drone, Araç rotalama, Matematiksel modelleme competition between companies, having the best quality standards and improving the services for customers are the main difficulties in a business environment.

The present business atmosphere requires the logistics activities to incorporate complex systems and communication ways. As a result of this definition, transportation becomes a significant function of logistics. Basically, it can be defined as the movement of goods, materials and people from one location to another. Transportation system includes land, air route, sea route, railway, river road and pipeline. In early years, transportation was made via animals such as donkey, horse, etc. After industrial revolution, human beings started to employ machines such as trains, cars and so on. Generally, trucks are very commonly used in short distance transportation. Since their invention in the beginning of the $20^{\text {th }}$ century, airplanes occupy an important part of overseas transportation because of their safety and speed. Nowadays, the advancement in technology enables us to carry goods with drones, which are 
Unmanned Arial Vehicles (UAVs). The price of drones have decreased with the development of technology. Currently, reputation of drones increases both in special uses and in commercial areas. For instance, unmanned aircrafts are exploited in agricultural maintenance, traffic monitoring, and in delivery services.

The high population in big cities leading to traffic jams that affect customer delivery time and customer satisfaction adversely constitutes the main motivation of this study. Utilization of autonomous drones in transporting merchandise will avoid bottlenecks in traffic, resulting in time efficient, less costly, and "green" service. The study aims to highlight another potential usage area of drones, which is drug delivery to pharmacies from a center, and Bakırköy district of İstanbul is chosen as the implementation region. The proposed two-stage methodology incorporates two mixed-integer linear programming models; one for the clustering problem of pharmacies in the abovementioned area, and another for the delivery routing problem of the drones.

The study is organized as follows: Section 2 gives the relevant literature in which clustering model, center of gravity model, and vehicle routing problem concepts are mentioned. The solution methodology is presented in Section 3, and the implementation results are provided in Section 4. The study is concluded in Section 5 and a short discussion on future perspectives is given. Finally, Section 6 lists the references used in the study.

\section{Literature review}

This section includes basic information and literature on drones, clustering model, center of gravity model, and vehicle routing problem.

\subsection{Drones}

Drones are considered as flying objects/vehicles without oneto-one human control. These drones can be classified as autonomous and remotely piloted. The term of "drone" was introduced to literature by Delmar S. Fahrney in 1936 [1]. Essentially, UAVs were used for military purposes after World War II. However, the purpose of employing UAVs then started to shift towards civil applications [2]. Drone photography and mapping issues, use of drone for aerial, stockpile and traffic monitoring are some application examples.

Drone delivery is a new and an innovative transportation approach to the present delivery system. It is understandable because drones can carry anything such as food, medicine, postal boxes etc., depending on their carrier capacity. Besides usage in delivery services, UAVs are employed for different purposes, such as for personal hobby.

Initially, the idea of exploiting drones for package delivery came out from Amazon. They designed a commercial drone for delivery operations named as "Amazon Prime Air", and targeted to reach the customers no more than half an hour [3] In addition, this drone could fly for 400 feet with a carrying capacity load of roughly 3 kilograms. Other worldwide companies such as, Google, Walmart, UPS, FedEx and DHL followed the same footsteps of Amazon in terms of employing drones in their logistics activities. For instance, DHL introduced a drone aiming to deliver medicine. The drone, which is called as "Parcelcopter", has a speed of $50 \mathrm{~km}$ and endurance about one and half hour [4]. Amazon and DHL have completed the tests and started delivery services for designated regions.
Figures 1 and 2 represent the drones used by Amazon and DHL, respectively. Another example is that Google, a retailer company, has a project for raising the number of drones in delivery. The project has different ideas in terms of the working principles of UAVs [5].

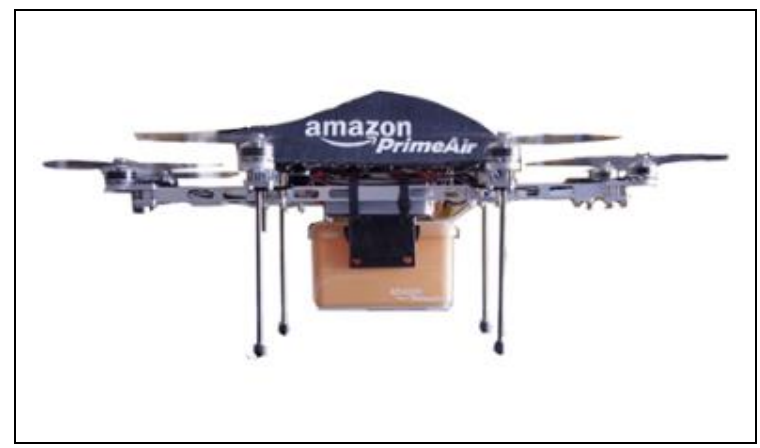

Figure 1: Amazon's design of drone model for delivery.

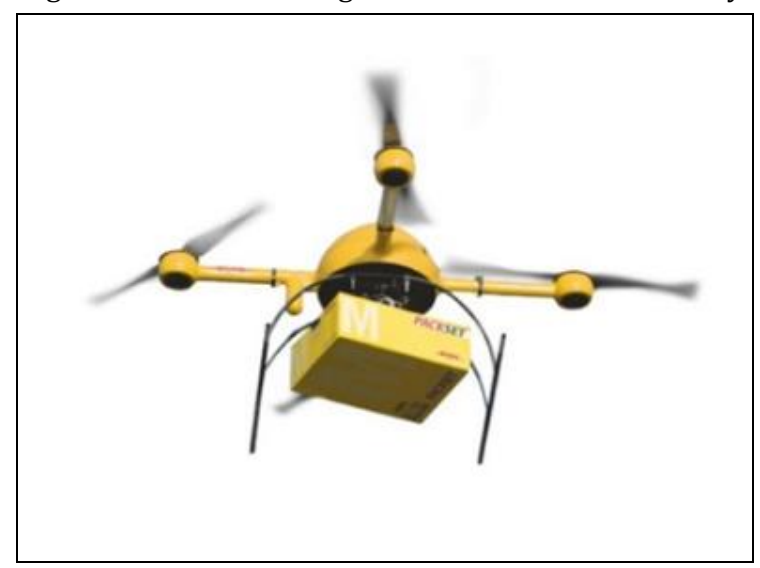

Figure 2: Parcelcopter, drone of DHL.

Nevertheless, there are rules, which are imposed by Federal Aviation Administration (FAA) in the U.S. that the companies have to obey [6]. Some of these rules are as follows:

- Drones can carry up to 25 kilograms,

- Maximum groundspeed is 100 miles per hour,

- At least three miles of weather visibility is required from the control station,

- Hazardous materials cannot be carried.

However, as stated by FAA, due to the high demand of using UAVs, most of the rules are waivable under certain conditions.

In Turkey, the Directorate General of Civil Aviation (DGCA) is the embedding body that imposes the rules not just for drones but also for all flying objects. In order to fly a drone, one needs to register herself/himself and her/his drone, which weighs 500 grams or more. Even if the flight permit is issued she/he cannot fly the drone everywhere such as high population area, close to the airport area and so on. More details about the restrictions are available in the Directorate General of Civil Aviation (DGCA) web site [7].

\subsection{Clustering model}

Data mining is one of the analytical tools that enables the analysis of multi-properties, the collection of necessary information and the understanding of the interrelationships of the data. Classification, clustering, prediction, decision trees 
and association rules are some commonly used data mining techniques [8]

Cluster analysis is a key method for data research, which consists of various steps relevant to each other. Clustering algorithms are based on classifying data with specific number of clusters by the help of similarities between them. Proximity criterion is the core of clustering algorithms. The idea is that, the objects in a cluster should have a resemblance. Hierarchical and partitional are two classes of clustering algorithms [9].

Nearly every field in industry is utilizing clustering algorithms. Çalıș et al. [10] performed such an analysis in the banking sector for examining customers who apply for a loan. Depending on the status of the customers, three clusters are identified at the end of the analysis.

\subsection{Center of gravity model}

Center of Gravity (CoG) is a method that is utilized for designating the location of a strategic place such as a warehouse, distribution center, etc. [11]. The location of these places is calculated with the data, which is relevant to the purpose of the place. For implementation of the methodology, demand of manufactured or distributed products, distribution costs, distance to target locations are the most common and important factors.

The formulas used for finding the coordinates of the center of gravity in a given system require the $x$ - and $y$-coordinates of the current facilities together with the volume of goods that will be moved to/from these facilities. The coordinates of the CoG are then calculated as a weighted average of the coordinates of the current facilities [12].

\subsection{Vehicle routing problem}

Vehicle Routing Problem (VRP) is essentially the comprehensive form of the Traveling Salesman Problem (TSP). It was first introduced in the paper entitled "The Truck Dispatching Problem" written by George Dantzig and John Ramser in 1959 as an algorithmic method that was applied to gasoline distribution [13].

The main interest of VRP is the delivery service of a company. It concerns how goods are transported from one or more loading place or places to unloading locations in sets of paths, and focuses on determination of sets of routes for satisfying all demands of customers and minimizing the entire transportation cost. It should be noted that, objectives of VRP may vary depending on the application; such as, minimizing the fuel cost and $\mathrm{CO}_{2}$ emission, or minimizing the number of vehicles in operation.

Typically, delivering goods from a located central depot to customers who have placed orders for goods becomes the main objective. In this case, the loaded vehicles leave the depot, and after delivery, return back empty to the depot. Another situation includes the operations in which empty vehicles depart from central depot to take orders and come back full. Moreover, another scenario is that empty vehicles start off to take orders from various objective areas and drop them to specified customer locations, and then come back as empty vehicles. VRPs can also be capacitated, include multiple depots, and have features like time windows.

In order to calculate the entire expenses that will be spent for each route, traveling cost and times between each loading and unloading locations must be known. To gain this information, the original map is converted to a graph. Figure 3 includes vertices representing the load/unload spots, and arcs indicating roads. These arcs indicate the lowest price between two points in the network. This looks similar to the Shortest Path Problem (SPP), which concentrates on finding the shortest road among a lot of optional paths [14].

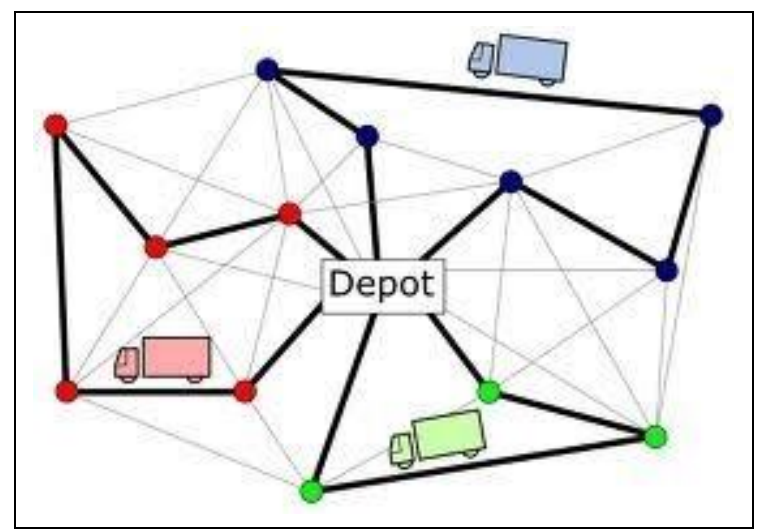

Figure 3: Vehicle routing problem diagram.

Methodologies, such as integer programming, can be used in finding the optimal routes for a fleet of vehicles [15]. However, since VRP is NP-hard, a remarkable number of heuristics and metaheuristics have also been suggested [16].

New models need to be developed/introduced for drone delivery, which is a novel approach. The work conducted by Greblicki and Walczyński [17] aims to examine the TSP algorithm for autonomous UAVs, in which the optimal routes are determined under variable wind conditions. The two VRP models proposed by Dorling et al. [18] for drone delivery include the features of multiple trips to the depot, and battery weight and payload weight effect on energy consumption. The authors use mixed-integer linear programming models to formulate the problems. Large runtimes of these models lead to the development of a simulated annealing heuristic, which can be employed in determining suboptimal solutions to practical scenarios. Results obtained underline the significance of drone reusage and battery size optimization.

Escalation in drone utilization has guided the literature to extend the classical VRP to the Vehicle Routing Problem with Drones (VRPD) in which a drone and a vehicle operate collectively to decrease delivery times.

The VRPD is handled from a worst-case perspective in the study by Wang et al. [19]. On the other hand, Poikonen et al. [20] broaden these worst-case results and analyze the connections with other VRPs. They conclude that the VRPD model has some important practical benefits.

Schermer et al. [21] suggest two heuristic algorithms to solve the VRPD, and evaluate their performance through experimentation with large scale examples. The authors highlight the benefit of using drone usage.

\section{Methodology}

The flowchart of the proposed methodology is displayed in Figure 4. As it can be seen, the first stage of the methodology starts with inputting the coordinates of the pharmacies in the Bakırköy district to the clustering model in order to obtain the clusters. In the second stage, one of these clusters is selected for further analysis, and using the CoG model, the coordinates of the drone center to be located in the cluster are calculated. Then, by the help of a VRP model, the drone routes that will be 
employed in delivering the drugs are determined. It is worthwhile to note that, the proposed methodology can be applied to all of the clusters in Bakırköy, as well as, to each district in İstanbul.

The following sub-sections explain the methodology with its mathematical models in detail.

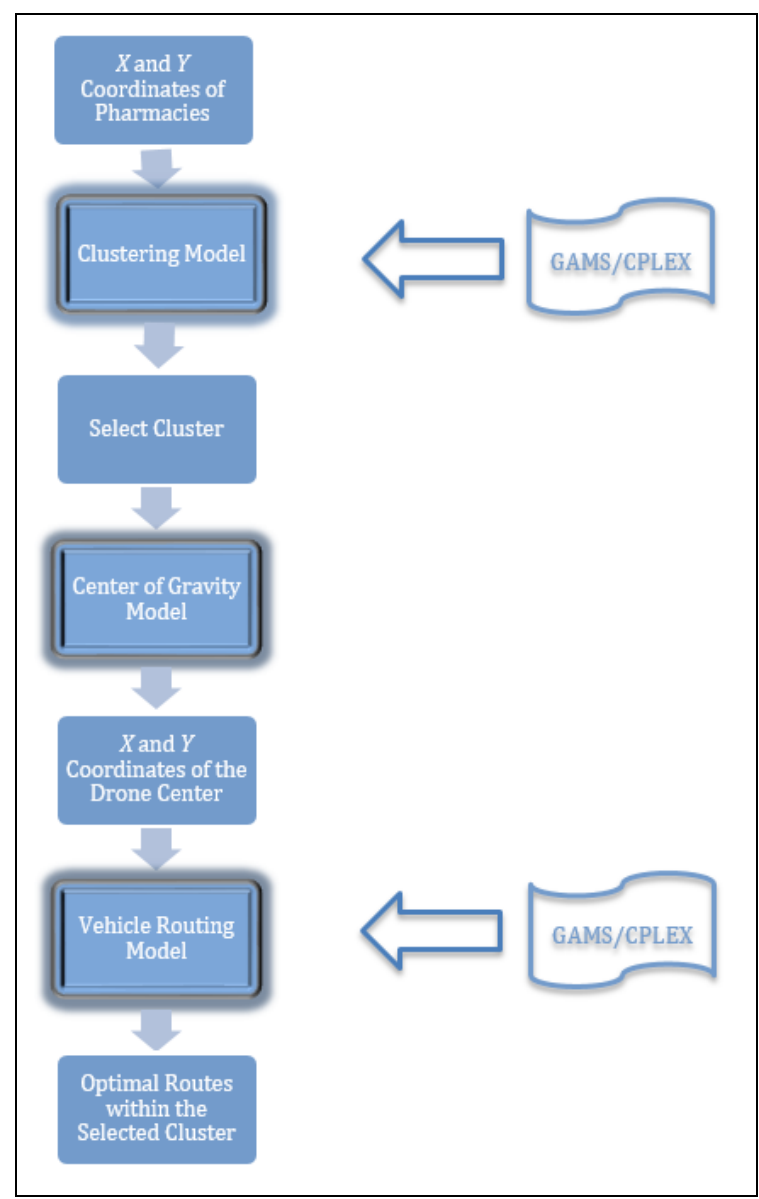

Figure 4: Flowchart of the methodology.

\subsection{Clustering model}

The clustering model, which is used to obtain groups of pharmacies according to their closeness values, is proposed by Akıș et al. [22].

\subsubsection{Indices, parameters and decision variables of clustering}

The indices, parameters and decision variables of the model are presented below:

\section{Indices:}

$i, j=$ pharmacy index

$$
(i, j=1, \ldots, l)
$$

$k=$ cluster index$$
(k=1, \ldots, K)
$$

\section{Parameters:}

$a_{i}=$ latitude of pharmacy $i$

$o_{i}=$ longtitude of pharmacy $i$

$d i s_{i j}=$ Euclidean distance between pharmacy $i$ and pharmacy $j$

$(\mathrm{km})$; calculated as in equation (1):

$$
d i s_{i j}=\sqrt{\left(a_{i}-a_{j}\right)^{2}+\left(o_{i}-o_{j}\right)^{2}}
$$

\section{Decision variables:}

$D_{\text {max }}=$ maximum diameter of the clusters that are constructed $D_{k}=$ diameter of cluster $k$

$X_{i k}=\left\{\begin{array}{c}1, \text { if pharmacy } i \text { belongs to cluster } k \\ 0, \text { otherwise }\end{array}\right.$

$N_{k}=$ number of pharmacies in cluster $k$

\subsubsection{Mathematical model of clustering}

The aim of the mixed-integer linear programming clustering model given below is to determine the optimal partitioning of 147 pharmacies in the Bakırköy district.

$$
\min z=D_{\max }
$$

The objective function (2) minimizes the maximum diameter of the clusters that are constructed.

\section{Subject to:}

$$
D_{k} \geq d i s_{i j} *\left(X_{i k}+X_{j k}-1\right) \quad \forall i, j, k
$$

Constraint (3) guarantees that the distance between two pharmacies $i$ and $j$ belonging to the same cluster $k$ should be less than the maximum diameter of that cluster.

$$
\sum_{k} X_{i k}=1 \quad \forall i
$$

Constraint (4) states that each pharmacy $i$ should be assigned to a cluster.

$$
D_{k} \leq D_{\max } \quad \forall k
$$

Constraint (5) calculates the maximum diameter of each cluster $k$.

$$
\sum_{i} X_{i k} \leq N_{k} \quad \forall k
$$

Constraint (6) determines the total number of pharmacies in each cluster $k$.

$$
\begin{array}{lc}
X_{i k}=\{0,1\} & \forall i, k \\
D_{\text {max }}, D_{k}, N_{k} \geq 0 & \forall k
\end{array}
$$

Constraints (7) and (8) define the decision variables of the model.

\subsection{Center of gravity model}

CoG method is employed to find the coordinates of the drone center. This center will act as a warehouse for both the landing and takeoff of drones, and the drugs that will be dispatched by them. The pharmaceutical depots do not share the dispatching information due to their privacy policies. In addition, visits to different pharmacies and talking to the pharmacists reveal the fact that, the daily demand volume of drugs changes with respect to promotions and seasonal effects such as vaccination periods. As a result, the daily demand volume is considered as one unit for each pharmacy in order to prevent the relocation of the drone center. Otherwise, the center must be relocated due to the demand fluctuations, which is financially and administratively undesirable.

\subsubsection{Indices, parameters and decision variables of CoG}

\section{Indices:}

$i=$ pharmacy index $\quad(i=1, \ldots, I)$

Parameters:

$C x_{i}=x$-coordinate (latitude) of pharmacy $i$ 
$C y_{i}=y$-coordinate (longitude) of pharmacy $i$

$V_{i}=$ demand of pharmacy $i$

\section{Decision variables:}

$X=$ latitude of the drone center

$Y=$ longitude of the drone center

\subsubsection{CoG formulas}

The formulas to calculate the coordinates of the drone center are given in equations (9) and (10):

$$
\begin{aligned}
& X=\frac{\sum_{i} V_{i} * C x_{i}}{\sum_{i} V_{i}} \\
& Y=\frac{\sum_{i} V_{i} * C y_{i}}{\sum_{i} V_{i}}
\end{aligned}
$$

\subsection{VRP model}

The main purpose of using a VRP model is to find the optimal routes for drug delivery while minimizing the total distance travelled. The following sub-sections present the mathematical model together with its basic assumptions.

\subsubsection{Basic assumptions}

- In the selected cluster, there are 16 pharmacies and one drone center,

- "Yeair Drone", which is the model used in the system, has a maximum carrying capacity of 5 kilograms. Hence, it is assumed that, when the drone arrives at the drone center, exactly 5 kilograms are loaded by an employee,

- Average speed of the drone is 100 kilometers/hour,

- The energy source of the drone is gasoline and its tank capacity is 1.5 liters,

- Maximum duration that the drone can travel is 30 minutes,

- Maximum distance that the drone can travel is 55 kilometers,

- Total service time consisting of landing and takeoff of the drone, and unloading of drugs at a pharmacy is 4 minutes,

- The capacity restriction is embedded in the maximum trip distance constraint. Hence, it is relaxed in the formulation.

\subsubsection{Indices, parameters and decision variables of VRP}

The indices, parameters and decision variables of the VRP are defined below:

\section{Indices:}

$$
i, j=\text { pharmacy index } \quad(i, j=1, \ldots, l)
$$

\section{Parameters:}

distance $_{i j}=$ distance between pharmacy $i$ and $j$ (meters)

time $_{i j}=$ flight duration of a drone between pharmacy $i$ and $j$ (minutes); calculated as in equation (11):

$$
\text { time }_{i j}=\text { distance }_{i j} * 60 / 100,000
$$

tservice $=$ total time required for landing and takeoff of a drone, and unloading of drugs at a pharmacy (minutes)

$M 1$ = a large number $/ 30 /$

$M 2$ = a large number $/ 3000 /$
MaxDur = maximum duration that a drone can travel (minutes)

MaxDist $=$ maximum distance that a drone can travel (meters)

\section{Decision variables:}

$X_{i j}=\left\{\begin{array}{c}1, \text { if node } j \text { is visited immediately after node } i \\ 0, \text { otherwise }\end{array}\right.$

$A T_{i}=$ arrival time of a drone to pharmacy $i$ (minutes)

$D_{i}=$ cumulative distance travelled by a drone until it arrives at pharmacy $i$ (meters)

\subsubsection{Mathematical model of VRP}

The proposed mixed-integer linear programming model is given below:

$$
\min z=\sum_{i=1}^{I} \sum_{\substack{j=1 \\ j \neq i}}^{I} \text { distance }_{i j} * X_{i j}
$$

The objective function (12) minimizes the total distance travelled by the drones.

\section{Subject to:}

$$
\sum_{\substack{i=1 \\ i \neq j}}^{I} X_{i j}=1 \quad \forall j, j \neq 1
$$

Constraint (13) guarantees that there must be exactly one incoming arc to pharmacy $j$ that originates either from the drone center of from another pharmacy.

$$
\sum_{\substack{j=1 \\ j \neq i}}^{I} X_{i j}=1 \quad \forall i, \quad i \neq 1
$$

Constraint (14) guarantees that there must be exactly one outgoing arc from pharmacy $i$ that terminates either at the drone center or at another pharmacy.

$$
A T_{1}=0
$$

Constraint (15) denotes that the arrival time of a drone to the center should be zero.

$$
\begin{gathered}
A T_{j} \geq A T_{i}+\text { time }_{i j}+\text { tservice }-M 1 *\left(1-X_{i j}\right) \\
\forall i, j, \quad i \neq j ; j>1
\end{gathered}
$$

Constraint (16) calculates the arrival time of a drone to pharmacy $i$.

$A T_{i}+$ time $_{i, 1}+$ tservice $\leq$ MaxDur

$\forall i, \quad i \neq 1$

Constraint (17) ensures that the total travelling time of a drone does not exceed its maximum trip duration.

$$
D_{1}=0
$$

Constraint (18) denotes that the cumulative distance travelled at the drone center should be zero.

$$
\begin{gathered}
D_{j} \geq D_{i}+\text { distance }_{i j}-M 2 *\left(1-X_{i j}\right) \quad \forall i, j, i \neq \\
j ; j>1
\end{gathered}
$$

Constraint (19) calculates the cumulative distance travelled by a drone until it arrives at pharmacy $i$.

$$
D_{i}+\text { distance }_{i, 1} \leq \text { MaxDist } \quad \forall i, \quad i \neq 1
$$

Constraint (20) ensures that the total distance travelled by a drone does not exceed its maximum trip distance. 


$$
\begin{array}{cc}
X_{i j}=\{0,1\} & \forall i, j \\
A T_{i}, D_{i} \geq 0 & \forall i
\end{array}
$$

Constraint (21) states that the associated variables should be binary, and Constraint (22) defines the non-negative decision variables.

\section{Implementation and results}

As mentioned before, Bakırköy district of İstanbul is selected as the implementation area of the proposed methodology. The analysis of the area displayed a total of 147 pharmacies, whose coordinates are found from Google maps. Using these coordinates as inputs, the clustering model presented in Section 3.1 is solved for clusters of 3, 4, 5 and 6 by GAMS/CPLEX software [23] in order to provide alternative options for the decision maker. Table 1 shows the comparison of different clusters. By taking into account factors such as, budget, obstacles in the area under consideration, marketing strategies and logistics opportunities, the decision maker can make her/his selection among the different clusters. Nevertheless, this selection may not necessarily lead to the case with the minimum objective value. In the present study, $k=6$ with the lowest maximum diameter value is chosen, which has 211.62 seconds of CPU time. Among the clusters of this solution, the second cluster having 16 pharmacies is picked out for further analysis. It should be noted that, this is a random selection and it is also possible to apply the whole methodology to the other clusters.

The pharmacies belonging to the selected cluster are listed in Table 2. The next step is to identify the location of the drone center that will deliver the drugs to these pharmacies, and the CoG method summarized in Section 3.2 is used to calculate the coordinates of this center with respect to the latitudes and longitudes of the 16 pharmacies in Cluster 2.
Table 1: Comparison of different clusters.

\begin{tabular}{|c|c|c|c|c|}
\hline Number of clusters & $\boldsymbol{k}=\mathbf{3}$ & $\boldsymbol{k = 4}$ & $\boldsymbol{k = 5}$ & $\boldsymbol{k = 6}$ \\
\hline $\begin{array}{c}\text { Objective function } \\
\text { value }\end{array}$ & 0.039 & 0.027 & 0.026 & 0.020 \\
\hline $\begin{array}{c}\text { Number of } \\
\text { pharmacies in each } \\
\text { cluster }\end{array}$ & $9-117-21$ & $\begin{array}{c}9-18-29 \\
-91\end{array}$ & $\begin{array}{c}4-33-87-5 \\
18-5\end{array}$ & $\begin{array}{c}4-16-38-18-5 \\
66-18\end{array}$ \\
\hline
\end{tabular}

Table 2: List of pharmacies in cluster 2.

\begin{tabular}{ll|}
\hline Ataköy Zuhal & Ataköy 2-5-6. Section \\
Pharmataköy & Ataköy 2-5-6. Section \\
Pınar & Ataköy 2-5-6. Section \\
Ata & Ataköy 2-5-6. Section \\
Zuhal & Ataköy 2-5-6. Section \\
Ataköy & Ataköy 3-4-11. Section \\
Serpil & Ataköy 3-4-11. Section \\
Lale & Ataköy 3-4-11. Section \\
Ataköy Martı & Ataköy 7-8-9-10. Section \\
Atrium & Ataköy 7-8-9-10. Section \\
Barıș & Ataköy 7-8-9-10. Section \\
Barış2 & Ataköy 7-8-9-10. Section \\
Martı & Ataköy 7-8-9-10. Section \\
Yosun & Ataköy 7-8-9-10. Section \\
Erina & Ataköy 2-5-6. Section \\
Asum & Zuhuratbaba \\
\hline
\end{tabular}

As a result of this calculation, the $x$ - and $y$-coordinates of the drone center are found as 28.8542 and 40.9825 , respectively. The exact location of these coordinates is in Barlas Küntay Park, a suitable point for a drone center that will act as a warehouse for medicines and drones. Figure 5 displays the location of the 16 pharmacies and the drone center in Cluster 2.

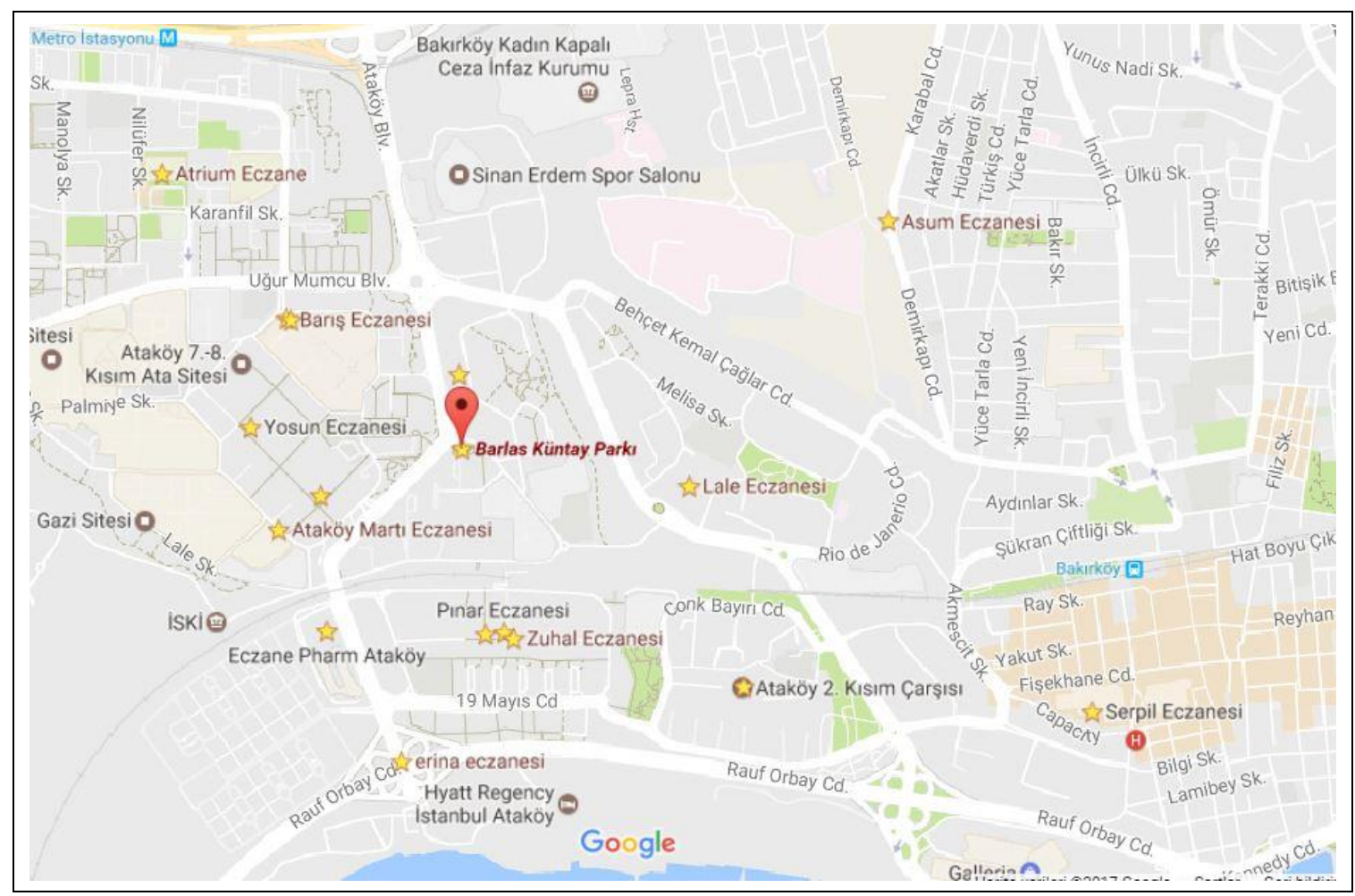

Figure 5: Location of the 16 pharmacies and the drone center (Barlas Küntay Park) in Cluster 2. 
The final step of the methodology involves the determination of the drug delivery routes in the selected cluster. For this purpose, the VRP model presented in Section 3.3 is solved by GAMS/CPLEX software [23]. The CPU time of this model is 13.28 seconds. The optimal solution gives three routes for the distribution of drugs in this cluster.

Figure 6 shows the map of Route 1. A drone is loaded and takes off from the drone center, dispatching drugs to pharmacies Zuhal, Pınar, Ataköy Zuhal, Serpil, Asum and returning back to the center. The total delivery time is 25.796 minutes, and the total travelling distance is 2992.55 meters.
Route 2 is demonstrated in Figure 7. The pharmacies in this route are as follows: Ataköy, Barış2, Barıș, Atrium and Yosun. Route 2 is completed in 25.27 minutes, with a total distance of 2149.36 meters.

The last route of the cluster is Route 3 , whose map is given in Figure 8. Distributing drugs from the drone center to pharmacies Martı, Ataköy Martı, Erina, Pharmataköy, Ata, and Lale, the route finishes in 29.76 minutes and the total trip covers 2859.21 meters.

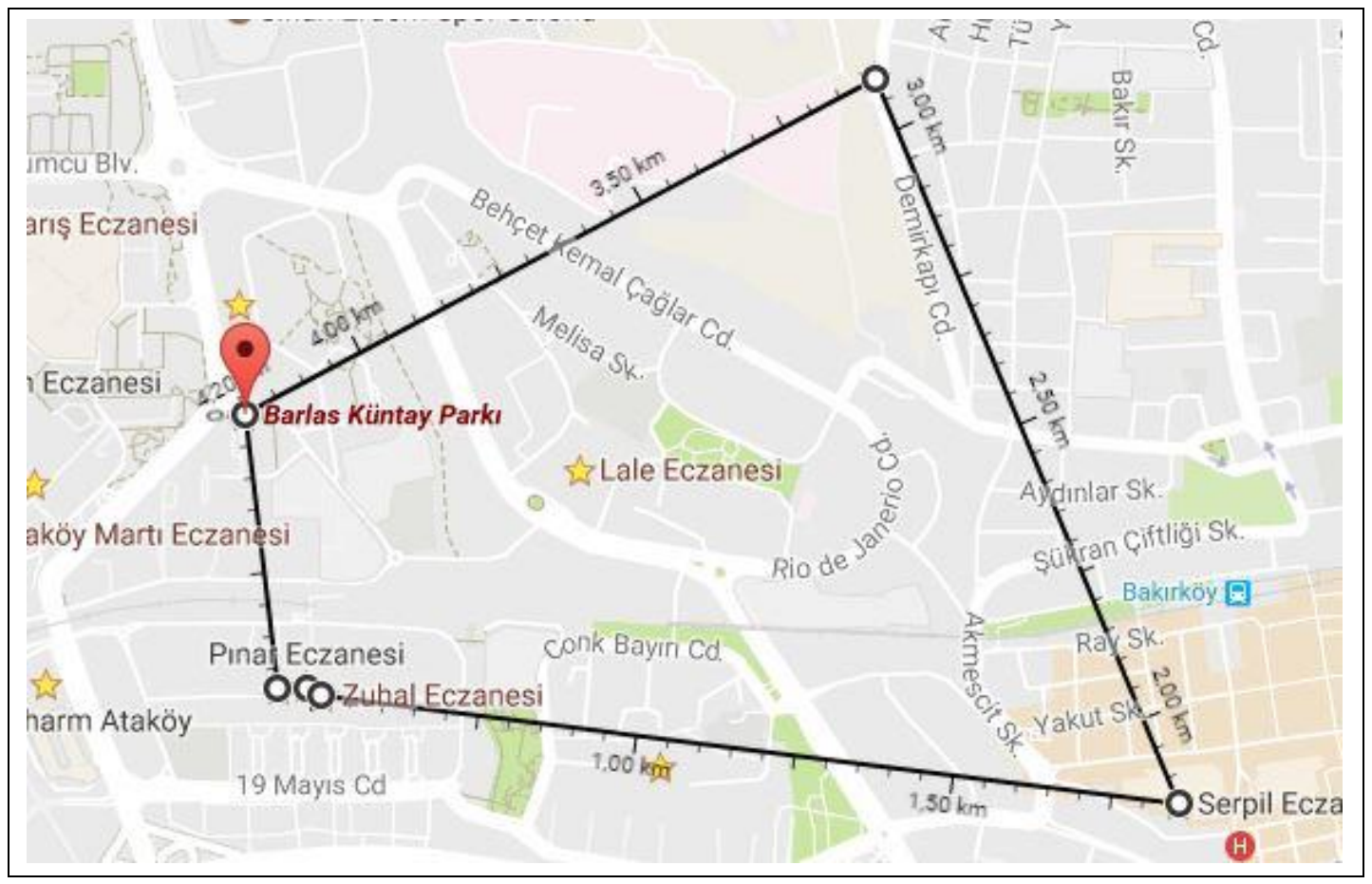

Figure 6: Route 1.

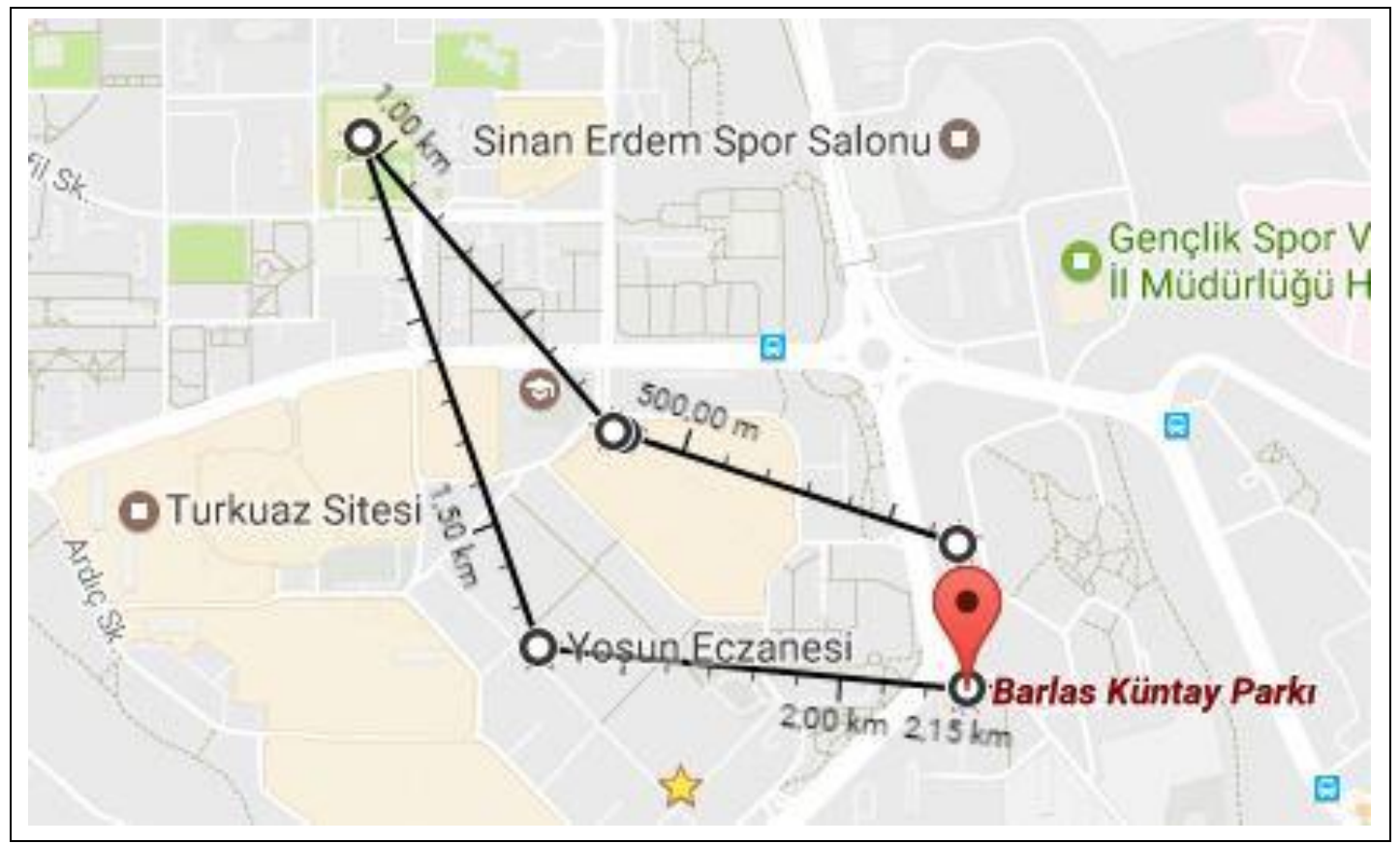

Figure 7: Route 2. 


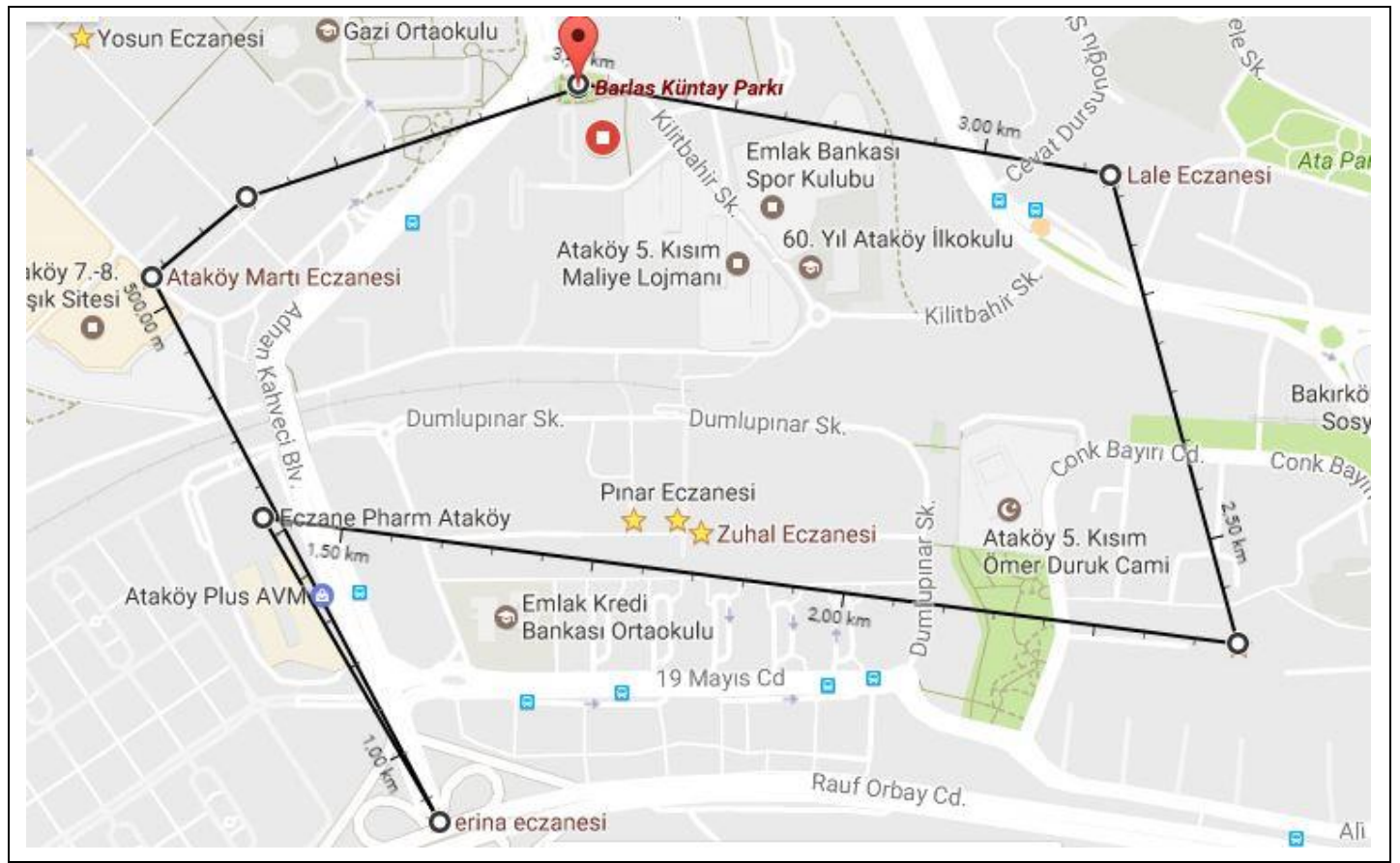

Figure 8: Route 3.

\section{Conclusion}

Delivering products in a timely manner is one of the objectives of logistics. Today's advanced technology leads the way to the utilization of drones in various sectors. In this study, daily drug delivery via drones is analyzed in the Bakırköy district of İstanbul.

The proposed methodology begins with clustering the 147 pharmacies located in this area by the help of a mixed-integer linear programming model. Then, one of these clusters is selected, and the center of gravity model determines the coordinates of the drone center that will be located in this cluster. The center will act as a warehouse for both the landing and takeoff of drones, and the drugs to be distributed. Finally, another mixed-integer linear programming model for finding the delivery routes between the center and pharmacies is proposed. Both mathematical models are solved using GAMS software and CPLEX solver.

The results are promising and indicate that, tackling the drug delivery problem with autonomous drones will be environmentally and financially beneficial. It should be noted that, although a car or a truck is capable of carrying more load per vehicle, a flying autonomous vehicle avoiding traffic congestion will lead to a time and cost efficient delivery. In addition to being advantageous in terms of total fuel consumption, since it won't require a driver, there will also be a saving in terms of salaries to be paid.

The proposed approach can be implemented with different products, as well as, in different locations. Delivery via drones will certainly provide a "green" solution to the logistics problem of goods suitable for this medium of transportation.

\section{References}

[1] Fahrney DS, RADM USN. "The birth of guided missiles". United States Naval Institute Proceedings, 106, 56-57, 1980.
[2] Keane JF, Carr SS. "A brief history of early unmanned aircraft". Johns Hopkins APL Technical Digest, 32(3), 558-569, 2013.

[3] BBC News. "Amazon Makes First Drone Delivery". http://www.bbc.com/news/technology-38320067 (2016).

[4] Deutsche Post DHL Group. "DHL Parcelcopter 3.0". http://www.dpdhl.com/en/media_relations/specials/pa rcelcopter.html (11.04.2018).

[5] Brar S, Rabbat R, Raithatha V, Runcie G, Yu A. "Drones for Deliveries". Sutardja Center for Entrepreneurship \& Technology, University of California, Berkeley, Technical Report, 2015.11.8, 2015.

[6] Federal Aviation Administration. "Summary of Small Unmanned Aircraft "Rule". https://www.faa.gov/uas/media/Part_107_Summary.pdf (2016).

[7] Directorate General of Civil Aviation (DGCA). http://web.shgm.gov.tr/en (11.04.2018).

[8] Dave M, Gianey R. "Different Clustering Algorithms for Big Data Analytics: A Review: Procedures in Jaipur, Rajsthan and India". Computer Science Department, Jagan Nath University, 2016.

[9] Xu R, Wunsch D. "Survey of clustering algorithms". IEEE Transactions on Neural Networks, 16(13), 645-678, 2005.

[10] Çalış A, Boyacı A, Baynal K. "Data mining application in banking sector with clustering and classification methods". Proceedings of the 2015 International Conference on Industrial Engineering and Operations Management, Dubai, United Arab Emirates, 3-5 March 2015.

[11] Onnela N. Determining the Optimal Distribution Center Location. MSc Thesis, Tampere University of Technology, Tampere, Finland, 2015. 
[12] Abbasi M. Storage, Warehousing and Inventory Management. Editors: Farahani RZ, Rezapour S, Kardar L. Logistics Operations and Management, Elsevier, 2011.

[13] Dantzig GB, Ramser JH. "The truck dispatching problem". Management Science, 6(1), 80-91, 1959.

[14] Toro E, Escobar A, Granada M. "Literature review on the vehicle routing problem in the green transportation context". Luna Azul, 42, 362-387, 2016.

[15] Blecha C, Goetschalckx M. "The Vehicle Routing Problem with Backhauls: Properties and Solution Algorithms". School of Industrial and Systems Engineering, Georgia Institute of Technology, Atlanta, Georgia, USA, 1992.

[16] Cordeau JF, Laporte G, Savelsbergh MWP, Vigo D. Vehicle Routing. Editors: Barnhart C, Laporte G. Handbook in OR \& MS, Elsevier, 2007.

[17] Greblicki J, Walczyński M. Determination of the Optimal Routes for Autonomous Unmanned Aerial Vehicle Under Varying Wind with Using of the Traveling Salesman Problem Algorithm. Editors: Saeed K, Homenda W. Computer Information Systems and Industrial Management, Springer, 2016.
[18] Dorling K, Heinrichs J, Messier G, Magierowski S. "Vehicle routing problems for drone delivery". IEEE Transactions on Systems, Man and Cybernetics: Systems, 47(1), 70-85, 2017.

[19] Wang X, Poikonen S, Golden, B. "The vehicle routing problem with drones: several worst-case results". Optimization Letters, 11(4), 679-697, 2017.

[20] Poikonen S, Wang X, Golden B. "The vehicle routing problem with drones: Extended models and connections". Networks, 70(1), 34-43, 2017.

[21] Schermer D, Moeini M, Wendt O. Algorithms for Solving the Vehicle Routing Problem with Drones. Editors: Nguyen N, Hoang D, Hong TP, Pham H, Trawiński B. Intelligent Information and Database Systems, Springer, 2018.

[22] Akış A, Sırma Z, Yalçın Z. Route Design in a Pharmaceutical Warehouse via Mathematical Programming. Unpublished Graduation Project, İstanbul Kültür University, İstanbul, Turkey, 2013.

[23] IBM. "ILOG CPLEX Optimization Studio". www.ibm.com/software/integration/optimization/cplex -optimization-studio (04.05.2017). 